\title{
20. MIDDLE CRETACEOUS BLACK SHALES AT SITE 530 IN THE SOUTHEASTERN ANGOLA BASIN ${ }^{1}$
}

\author{
Dorrik A. V. Stow, Grant Institute of Geology, University of Edinburgh, Edinburgh, Scotland, \\ EH9 3JW, United Kingdom \\ and \\ Walter E. Dean, U.S. Geological Survey, Denver, Colorado
}

\begin{abstract}
The middle Cretaceous black shale interval at Site 530 is $170 \mathrm{~m}$ thick and late Albian to Coniacian in age. The organic-carbon-rich sediments occur as 260 separate beds (average $4 \mathrm{~cm}$, maximum $60 \mathrm{~cm}$ thick) and make up less than $10 \%$ of the recovered section. Associated lithologies are greenish, grayish, and reddish mudstones, marlstones, and rare limestones. Organic-carbon contents of the black shales average about 5\% (maximum 16\%), and of the interbedded sediments, less than $0.5 \%$. Careful study of the sedimentary and biogenic structures and composition and review of paleoceanographic conditions in the Angola Basin indicate that a complex interplay of processes controlled black shale accumulation. Relatively low oxygen concentrations in sediment and bottom waters occurred periodically, and conditions locally may have been anoxic or near anoxic both in the basin and on the continental margin. Pelagic, hemipelagic, and turbiditic depositional processes all operated to varying degrees at different times.
\end{abstract}

\section{INTRODUCTION}

Drilling at many DSDP sites has encountered strata containing relatively high concentrations of organic matter ( $>1 \%$ total organic carbon). Such organic-carbonrich strata are particularly common in Early to middle Cretaceous sections of the North and South Atlantic oceans (Arthur and Natland, 1979; Weissert, 1981; Dean and Gardner, 1982) and were cored in the lower part of Hole 530A (lithologic Unit 8, Fig. 1; see Site 530 summary chapter). In this chapter we refer to these organiccarbon-rich sediments as "black shales" although not all are strictly black fissile mudstones.

The widespread occurrence of Cretaceous black shales has led to several generalized and simplified models to explain their origin. Currently the three most popular models invoke giant stagnant basins, oceanwide expanded oxygen minima, or a rapid supply of organic matter along basin margins (e.g., Demaison and Moore, 1980). However, detailed analyses of black shales from any one area or site clearly show that a much more complex interplay of controls was operative during accumulation of the black-shale facies.

Our primary aim in this chapter is to document the sedimentary characteristics of black shales from Site 530 . We also outline briefly what is known from other sources about the mid-Cretaceous Angola Basin and South Atlantic Ocean, and hence deduce some of the factors that we believe influence the accumulation of the black shale facies. Other chapters in this volume deal in more detail with the organic geochemistry (Meyers, Brassell, and Huc, Deroo et al., Brassel, this volume) and inorganic geochemistry (Dean and Parduhn, Dean, Arthur, and Stow, this volume) of these deposits.

\footnotetext{
${ }^{1}$ Hay, W. W., Sibuet, J.-C., et al., Init. Repts. DSDP, 75: Washington (U.S. Govt.
}

\section{BLACK SHALE CHARACTERISTICS}

The black shale facies at Site 530 makes up just less than $10 \%$ of the $170 \mathrm{~m}$ of section above basement from late Albian to Coniacian (lithologic Unit 8). It is not a thick, uniform, organic-carbon-rich interval but occurs as $\mathbf{2 6 0}$ individual beds ranging in thickness from less than 1 to $62 \mathrm{~cm}$, and averaging $4.3 \mathrm{~cm}$ (Table 1, Fig. 2). These beds are intercalated with reddish, greenish, and grayish mudstones, calcareous mudstones, marlstones, and rare limestones which form a variable proportion of the section. Green and then red mudstones that contain up to $40 \% \mathrm{CaCO}_{3}$ are the dominant lithologies in the $65 \mathrm{~m} \mathrm{im}$ mediately above basement (Cores 99-105); black shales reach a maximum of about $50 \%$ of the recovered section in the Turonian from 65 to $75 \mathrm{~m}$ (Cores 97 and 98); red mudstones with little carbonate are dominant through the remaining upper $95 \mathrm{~m}$ of Unit 8 (Cores 87-96) (Fig. 2). The overall sedimentation rate throughout is relatively low-mostly less than $1 \mathrm{~cm} / 1000 \mathrm{yr} .(<10 \mathrm{~m} /$ $10^{6} \mathrm{yr}$.).

Four common associations of black shale and related facies occur repeatedly (Fig. 3). The most common, occurring in about $60 \%$ of the cases, is a simple alternation of green mudstone or calcareous mudstone with black shale. The contacts between black and green are mostly bioturbated, and the black shales may be closely spaced, widely spaced, or occur as isolated beds within the green mudstones (Fig. 3A). The other common associations, occurring in about $30 \%$ of the cases, begin with a lightcolored limestone or marlstone and grade up through light gray calcareous mudstone and dark gray mudstone to black shale. The black shale is overlain by gray mudstone (Fig. 3B) or gray muddy sandstone (Fig. 3C) and then by green mudstone. More rarely (about $5 \%$ ), a thin black shale is sandwiched by a thin "halo" of green within a red mudstone sequence (Fig. 3D). In no case is 


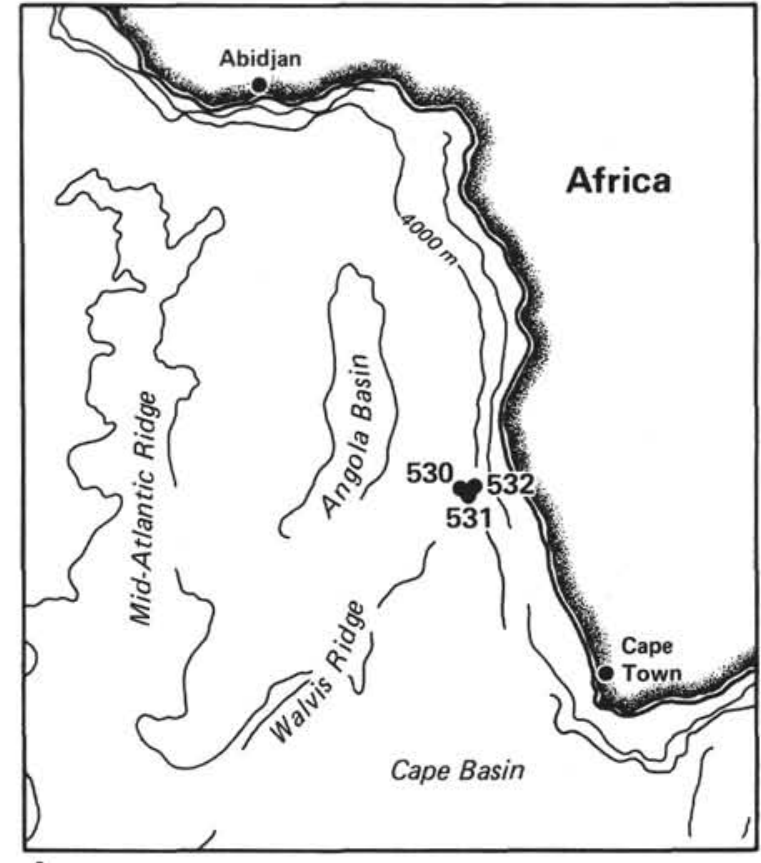

A

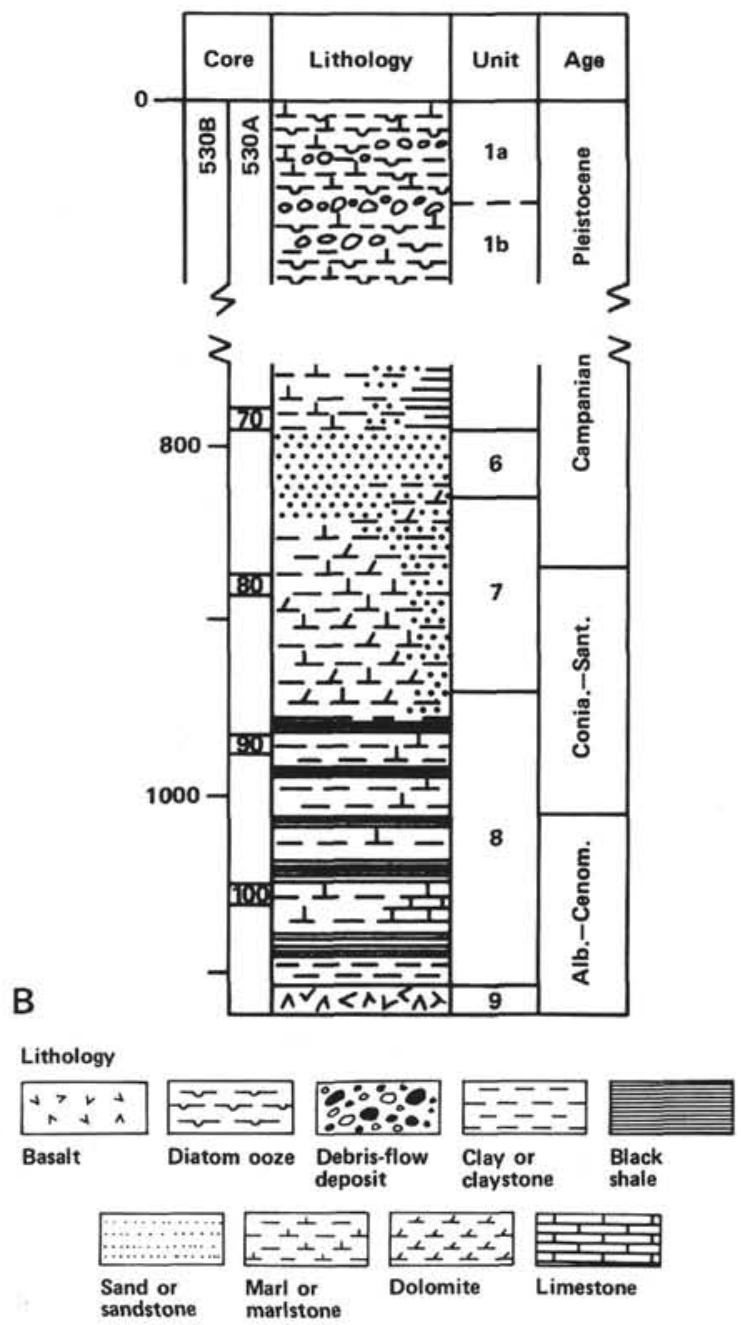

Figure 1. A. Map showing location of Site 530. B. Lithostratigraphy of black-shale interval, Unit 8, Albian to Coniacian. (Revisions of stratigraphic ages are given in Steinmetz et al., this volume.) a black-shale bed overlain or underlain by red claystone; there is always at least a thin bed of green or gray reduced sediment separating a black-shale bed from red oxidized sediment.

The black shales are not always laminated throughout, but show a variety of additional sedimentary structures (Fig. 4, Plates 1 and 2). About $80 \%$ of the beds are at least partly laminated, and this lamination appears to be of two basic types. Either (1) there is very fine-scale fissility marked by the parallel alignment and streakingout of dark-colored organic and clayey material, commonly draped around small silt lenses, or (2) there are distinct to indistinct light gray silt laminae within the darker-colored mudstone. Many of these silt laminae clearly form part of very thin-bedded (commonly $<1 \mathrm{~cm}$ ) fine-grained turbidites, and show grading, low-amplitude rippling, scoured bases, etc. The gray silty bases of the turbidites grade upward into black, massive or fissile mudstone tops. Such turbidites occur within parts of at least $25 \%$ of the black-shale beds.

Bioturbation is common throughout the $170 \mathrm{~m}$ of Unit 8 and is present to some degree in $40 \%$ of the black shale beds themselves. In the transition from green mudstone to black shale the burrows commonly become smaller and less abundant upwards. Where burrow types can be recognized, large Zoophycos in the green mudstones give way upward to large then small Planolites and finally to very small Chondrites just below the black shale. The same sequence is reversed when passing upwards from black shale to green mudstone, although some thin black-shale beds may be partly or totally destroyed by subsequent large-scale burrowing. The thicker beds commonly contain thin intervals of micro-bioturbation and Chondrites-type burrows, often as a slightly grayer layer within the black.

The interbedded multicolored facies are, for the most part, more thoroughly bioturbated than the black shales, so that only about $5 \%$ of the section has clear turbidite lamination and other structures remaining. There are both significant differences and similarities in composition between the black shales and associated red and green mudstone facies (Dean and Parduhn, Stow and Miller, this volume). There is little consistent variation in clay mineralogy between facies. Smectite ranges between $10 \%$ and $60 \%$, mixed-layer minerals 2 and $10 \%$, illite 35 and $75 \%$, and chlorite 1 and $15 \%$. Chlorite is most abundant in the lower $30 \mathrm{~m}$ of Unit 8, and kaolinite is absent or present in trace amounts only. The silty layers throughout also have variable mineralogy that is apparently not related to any particular facies. Silt layers commonly are rich in quartz and clays, sometimes with carbonate cement, and have accessory opaque minerals, glauconite, feldspar, micas, and organic material. Some silt layers are rich in volcanic glass and other debris.

Carbonate is more unequally partitioned, being very low to absent in the black shales, up to $40 \%$ in the red and green mudstones, and $50-90 \%$ in the pale red and green marlstone and limestone beds. The lower half of the unit is more carbonate-rich than the upper. Nannofossils and foraminifers also are rare or absent in the black shales. 
Table 1. Black shale statistics, Hole 530A, Angola Basin.

\begin{tabular}{|c|c|c|c|c|c|c|c|c|c|c|}
\hline & \multirow[b]{2}{*}{ Core } & \multirow{2}{*}{$\begin{array}{l}\text { Core } \\
\text { length } \\
\text { recovered } \\
(\mathrm{cm})\end{array}$} & \multirow{2}{*}{$\begin{array}{l}\text { No. of } \\
\text { black } \\
\text { shale } \\
\text { beds }\end{array}$} & \multirow{2}{*}{$\begin{array}{c}\text { Total } \\
\text { thickness } \\
\text { of black } \\
\text { shale beds } \\
(\mathrm{cm})\end{array}$} & \multirow{2}{*}{$\begin{array}{c}\text { Average } \\
\text { thickness } \\
\text { (cm) }\end{array}$} & \multirow[b]{2}{*}{$\begin{array}{l}\text { Standard } \\
\text { deviation }\end{array}$} & \multirow{2}{*}{$\begin{array}{l}\text { Percent } \\
\text { of total } \\
\text { core } \\
\text { thickness }\end{array}$} & \multicolumn{3}{|c|}{ Percent organic carbon } \\
\hline & & & & & & & & $\begin{array}{l}\text { Black } \\
\text { shale }\end{array}$ & $\begin{array}{l}\text { Gray } \\
\text { shale }\end{array}$ & Other \\
\hline & 86 & 935 & 1 & 5 & 5 & & 1 & 2.0 & 1.3 & $0.2 ; 0.3$ \\
\hline & 87 & 703 & 12 & 52 & 4.2 & 2.5 & 7.6 & $5.4 ; 6.2$ & 1.3 & $0.2 ; 0.3$ \\
\hline & 88 & 448 & 5 & 25 & 5.0 & 2.1 & 5.6 & $9.7 ; 2.8$ & & 0.1 \\
\hline & 89 & 922 & 9 & 23 & 2.6 & 1.6 & 2.5 & 9.6 & & \\
\hline & 90 & 446 & 5 & 23 & 4.6 & 2.1 & 5.2 & 10.5 & & 0.6 \\
\hline & 91 & 574 & 1 & 2 & & & & & & 1.2 \\
\hline & 92 & Disturbed & & & & & & & & \\
\hline & 93 & 918 & 12 & 38 & 3.2 & 1.9 & 4.0 & & & $0.9 ; 0.8 ; 0.2 ; 0.1$ \\
\hline & 94 & 273 & 5 & 15 & 3.0 & 2.0 & 5.5 & 12.3 & & 0.3 \\
\hline & 95 & 656 & 12 & 35 & 2.9 & 4.0 & 5.3 & 1.7 & & 0.2 \\
\hline & 96 & 795 & 19 & 70 & 3.7 & 2.5 & 8.8 & 5.8 & 1.8 & $0.1 ; 0.4$ \\
\hline & 97 & 607 & 30 & 316 & 10.5 & 12.5 & 52 & $8.0 ; 7.3$ & & 0.2 \\
\hline & 98 & 501 & 58 & 180 & 3.1 & 4.3 & 36 & $1.4 ; 8.0$ & & $0.3 ; 0.5$ \\
\hline & 99 & 735 & 25 & 66 & 2.6 & 2.5 & 9.0 & 1.7 & 0.4 & 0.2 \\
\hline & 100 & 672 & 19 & 79 & 4.2 & 5.4 & 12 & 12.0 & 1.9 & 0.3 \\
\hline & 101 & 995 & 9 & 46 & 5.1 & 4.8 & 4.5 & 4.5 & 5.1 & $0.9 ; 1.3$ \\
\hline & 102 & 800 & 4 & 28 & 7.0 & 3.3 & 3.2 & 3.5 & $1.2 ; 1.7$ & 0.4 \\
\hline & 103 & 600 & 3 & 13 & 4.3 & 4.9 & 2.2 & 2.2 & 7.1 & \\
\hline & 104 & 790 & 4 & 22 & 5.5 & 2.6 & 7.8 & 2.8 & 5.2 & $0.4 ; 0.5 ; 0.6 ; 0.2$ \\
\hline & 105 & 800 & 16 & 79 & 5.0 & 5.0 & 9.8 & 9.8 & 5.3 & $0.2 ; 0.2 ; 0.2$ \\
\hline Totals: & 20 & $13,170^{\mathrm{a}}$ & 260 & 1105 & $4.3^{b}$ & & 8.4 & 5.7 & 1.2 & 0.3 \\
\hline
\end{tabular}

Geochemical analyses show marked concentrations of the trace elements As, Cd, Co, Cr, $\mathrm{Cu}, \mathrm{Mo}, \mathrm{Ni}, \mathrm{Pb}$, $\mathrm{V}$, and $\mathrm{Zn}$ in the black shales relative to interbedded red and green mudstones. Concentrations of $\mathrm{Ba}$ and $\mathrm{Fe}$ generally are higher in the red than in green mudstones or black shales, whereas concentrations of $\mathrm{Mn}$ are higher in the green than red mudstones, and much lower in black shales. Chemical mobilization during diagenesis may have further concentrated the most mobile elements $(\mathrm{Ba}, \mathrm{Co}, \mathrm{Ni}, \mathrm{Fe})$ in the black shales towards the top of the unit (Dean and Parduhn, this volume).

Organic carbon is high and variable (average 5.4\%, maximum $16 \%$ ) in the black shales, moderately high in the grayish-black shales (average 1-2\%), and low in the other lithologies (average $0.3 \%$, Meyers, Brassell, and Huc, this volume). The organic matter is dominantly marine with minor terrestrial input (Deroo et al., Katz, and Meyers, Brassell, and Huc, all this volume), and it appears that a low terrestrial supply may have been constant through all the facies, whereas increased marine supply characterized the black shales (see Brassell, this volume).

\section{MID-CRETACEOUS ANGOLA BASIN}

From previous work we know something about the oceanographic and sedimentary characteristics of the South Atlantic Ocean and Angola Basin during the middle Cretaceous (LePichon et al., 1978; van Andel et al., 1977; Bolli, Ryan et al., 1978). The Angola Basin was relatively narrow (about $300-400 \mathrm{~km}$ wide), restricted by the Walvis Ridge-Rio Grande Rise to the south and by the closure of Africa against South America to the north, and was a maximum of $3.5 \mathrm{~km}$ deep. The climate was warm, surface and bottom waters were both warm (about $30^{\circ}$ and $15^{\circ} \mathrm{C}$, respectively, Barron et al., this volume) and saline (Brass et al., 1982). Sea levels worldwide were high, leading to broad shallow continental shelves, flooded estuaries, and increased evaporation especially at low latitudes.
Normal pelagic, hemipelagic, and turbiditic sedimentation processes all were operating in the basin, but with a reduced supply of terrestrial material and low accumulation rates overall. Ten other DSDP sites in the South Atlantic have recovered mid-Cretaceous strata (Barker, Dalziel et al., 1977; Supko, Perch-Nielsen et al., 1977; Bolli, Ryan et al., 1978; Ludwig and Krasheninnkov, 1980). To the south, Sites $327,328,330$, and 511 on the Falkland Plateau recovered mostly open-marine, oxygenated sediments, but with older Cretaceous to Jurassic organic-carbon-rich strata of variable lithology at Sites 330 and 511. In the Cape Basin, Site 361 recovered reddish mudstones and dark gray shales with organic carbon contents rarely as much as $1 \%$. Sites 356 and 357 on the São Paulo Plateau and Rio Grande Rise are composed of interbedded marlstones, chalks, and limestones. On Walvis Ridge, Site 363 showed five thin black-shale horizons within a sequence of marlstone and mudstone. The sequence at Site 364 on the Angola Basin slope is very similar to that at Site 530 with maximum black shale development that is approximately synchronous. Site 365 on the Angola Basin rise had indications of thin black shale layers in a displaced "slump" unit.

\section{BLACK SHALE MODEL}

Any model for black shale deposition at Site 530 needs to explain the 260 separate organic-carbon-rich layers that form less than $10 \%$ of a dominantly organic-carbonpoor bioturbated, oxidized facies, that occur with irregular periodicity $(9,600$ to $393,000 \mathrm{yr}$.), and that show variable structures, thicknesses, and organic-carbon contents. The black shales do not appear to have been deposited by any single process but show evidence for both turbiditic and pelagic deposition, so that the black shale "events" were superimposed on normal basinal sedimentation.

In order to explain this complexity and variability of mid-Cretaceous organic-carbon-rich facies at Site 530, 


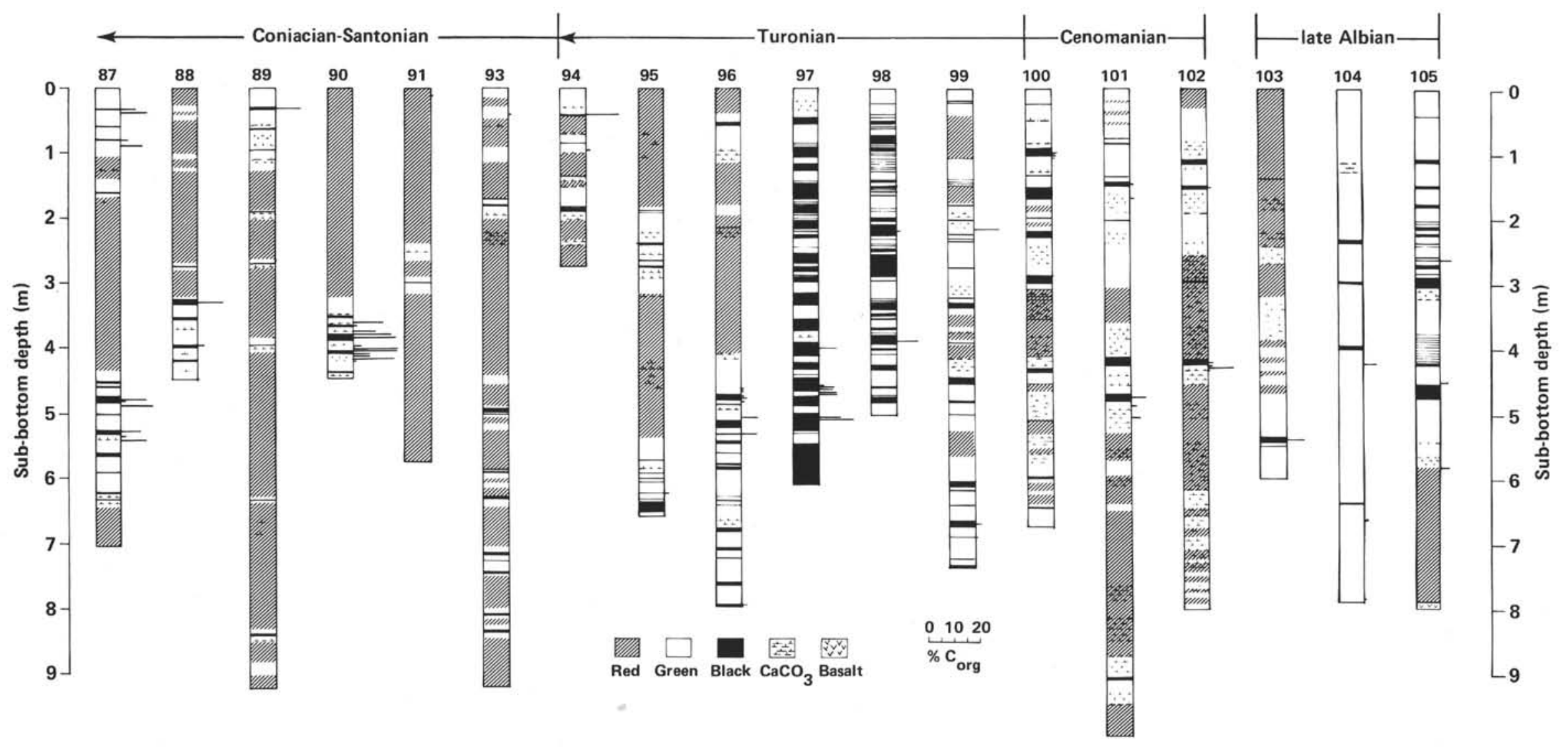

Figure 2. Distribution of black shales and associated facies, Cores 87 to 105, Hole 530A. 

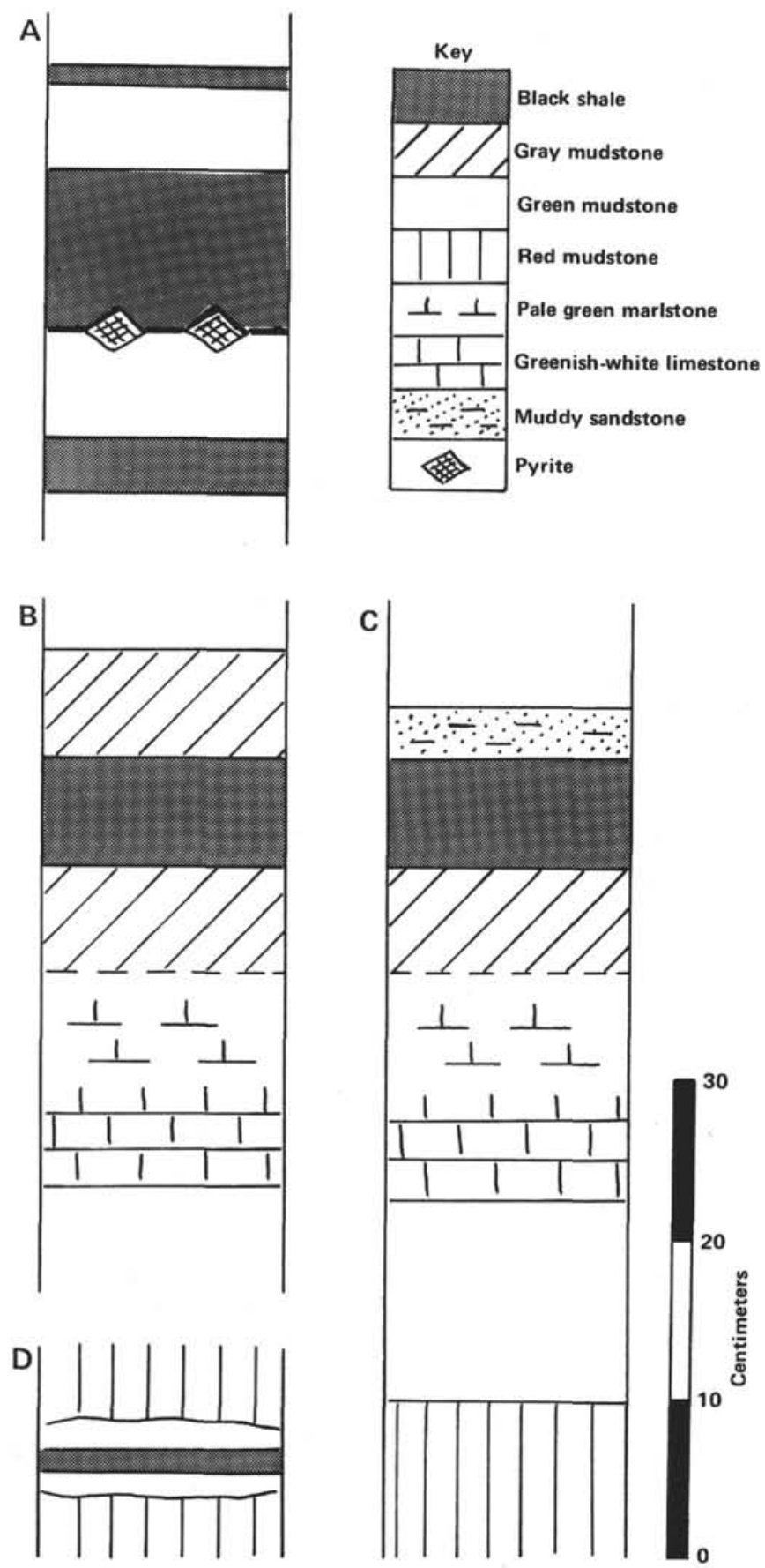

Figure 3. Typical black-shale sequences from Site 530: A. Occurs about $60 \%$ of the time. B. and C. together, about $30 \%$. D. less than $5 \%$.

we need to consider a range of factors that were probably operating in the Angola Basin at this period.

1) Factors acting to reduce seawater oxygen content (see discussions by Arthur and Natland, 1979; Demaison and Moore, 1980; Tissot et al., 1980): (a) The relatively small, silled basin would restrict circulation and tend to produce density stratification of the water column; (b) The high temperature and salinity of the bottom water would result in lower dissolved oxygen content; (c) The high sea levels would result in transgression of low-lying land areas and possibly increase the supply of terrestrial plant material seawards, and also stimulate marine plankton productivity over broad shelves, both factors tending to produce poorly oxygenated shelf waters and an increased supply of organic matter; (d) Increased evaporation over wide shelves would produce saline waters (also poor in oxygen) that would tend to spread dense, oxygen-depleted waters to the basin floor, increasing stratification.

2) Factors acting to increase seawater oxygen content (Brass et al., 1982): (a) The normal wind-forced advection of water masses; (b) Normal geothermal heating of the basin floor; (c) Circulation and overturn via saline waters, turbidity currents, and spillover from the Cape Basin to the south.

3) We are less certain about factors acting to increase the supply of organic material to the sediments (see discussion by Schlanger and Jenkyns, 1976; Cornford, 1979; Welte et al., 1979): (a) Surface productivity in the open ocean or over shelves probably was subject to temporal variations; (b) Similarly, the supply of terrestrial organic matter would be temporally and spatially variable, dependent on climate, rivers, etc,; (c) Turbidity currents would serve to transport both organic-carbon-rich and organic-carbon-poor sediments from the shelf and slope to the basin; (d) The rate of sedimentation of both organics and inorganics would affect supply, burial, and preservation of organic carbon-in the Angola Basin, sedimentation rates were low on average, but clearly variable.

4) We are also uncertain about temporal and spatial variability of factors and conditions within the Angola Basin during the mid-Cretaceous (see regional syntheses by Bolli, Ryan et al., 1978; LePichon et al., 1978): (a) Some climatic cyclicity probably occurred and would have affected a number of the factors outlined above; (b) Restricted shelf basins or coastal lagoons may have provided localized temporary sinks for organic matter; (c) Redeposition, largely by turbidity-currents, would also be localized.

It appears, then, that the bottom waters and sediments at Site 530 in the Angola Basin were sufficiently oxygenated during most of the middle Cretaceous to support an active infauna and to remove most of the organic carbon supplied so that red, oxidized sediment accumulated. However, for much of the time, the bottom waters were relatively depleted in oxygen (see factors $1 \mathrm{a}-\mathrm{d}$ above) and/or the rate of supply of organic matter was greater so that the underlying sediments were reduced and green sediments were produced. During these periods of oxygen-deficient water and/or sediment, several of the factors outlined above periodically combined to produce a diagenetic environment within the sediment (and probably for some distance above) that was (just) anoxic. This allowed preservation of organic carbon and accumulation of gray or black mud within a green mud sequence. With subsequent diagenesis and compaction many of these developed the fissility and color of true "black shales." Although such anoxic or near-anoxic conditions occurred periodically throughout the entire period of deposition of lithologic Unit 8 (late Albian 


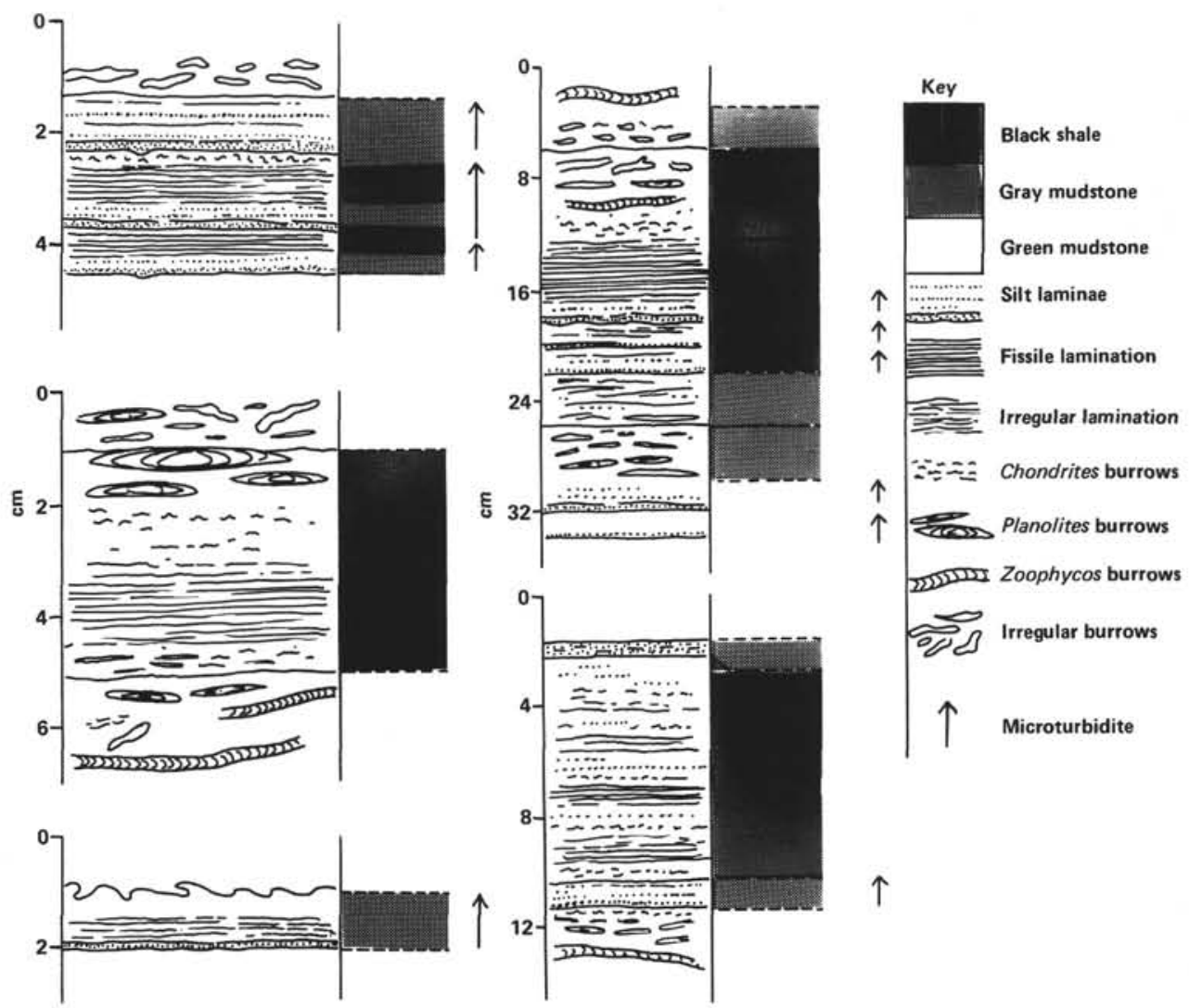

Figure 4. Details of sedimentary structures that are typical of black shales and adjacent layers from Site 530.

to Coniacian), the depositional system within the Angola Basin, and probably the entire mid-Cretaceous Atlantic Ocean, was more delicately poised with respect to supply of organic matter and oxygen concentrations in water masses during the early Turonian, so that more organic matter accumulated and was preserved, as indicated by the increased frequency of black-shale beds in Cores 97 and 98 (Fig. 2).

Even with detailed inspection of the black shales at Site 530 , it is not possible to isolate the factors that were most influential in their formation and diagenesis. We suspect different factors may have had more weight at different times and for different beds. In Figure 5A we summarize the range of conditions that may have contributed to anoxic sedimentation. At times, turbidity currents transported organic-carbon-rich sediments from the shelf and slope to the basin; at other times, hemipelagic material rich in organic matter settled through an anoxic or near-anoxic water column and was preserved in anoxic sediments. In Figure 5B the delicate balance has been tipped (very slightly) in favor of oxic sedimentation, through bioturbation and accumulation of green or red muds, depending upon dissolved oxygen concentrations in sediments and/or bottom waters. Finally, Figure $5 \mathrm{C}$ shows the importance of lateral variability on sediment types and processes within the Angola Basin and surrounding areas at any one time during the middle Cretaceous. Preliminary comparison with other Cretaceous black shales in the North and South Atlantic suggest that this more variable and complex model of sedimentation is more realistic than the several simplified models that have been proposed previously.

\section{ACKNOWLEDGMENTS}

DAVS acknowledges personal support from the Natural Environment Research Council, U.K. He would also like to thank the secretarial and technical staff at the Grant Institute of Geology, and Alan E. Kemp and Chris Cornford for reviewing the manuscript.

\section{REFERENCES}

Arthur, M. A., and Natland, J. H., 1979. Carbonaceous sediments in the North and South Atlantic: The role of salinity in stable stratification of Early Cretaceous basins. In Talwani, M., Hay, W. W., and Ryan, W. B. F. (Eds.), Deep Drilling Results in the Atlantic Ocean: Continental Margins and Paleoenvironment: Washington (Am. Geophys. Union, Maurice Ewing Series), 3:375-401.

Barker, P. F., Dalziel, I. W. D., et al., 1977. Init. Repts. DSDP, 36: Washington (U.S. Govt. Printing Office).

Bolli, H. M., Ryan, W. B. F., et al., 1978. Init. Repts. DSDP, 40: Washington (U.S. Govt. Printing Office).

Brass, G. W., Southam, J. R., and Peterson, W. H., 1982. Warm saline bottom water in the ancient ocean. Nature, 296:620-623.

Cornford, C., 1979. Organic deposition at a continental rise: Organic geochemical interpretation and synthesis at DSDP Site 397, eastern North Atlantic. In von Rad, U., Ryan, W. B. F., et al., Init. Repts. DSDP, 47, Pt. 1: Washington (U.S. Govt. Printing Office), 503-510.

Dean, W. E., and Gardner, J. V., 1982. Origin and geochemistry of redox cycles of Jurassic to Eocene age, Cape Verde Basin (DSDP Site 367), continental margin of northwest Africa. In Schlanger, S. O., and Cita, M. B. (Eds.), Nature and Origin of Cretaceous Organic Carbon-Rich Facies: London (Academic Press), pp. 55-78. 
Demaison, G. J., and Moore, G. T., 1980. Anoxic environments and oil source bed genesis. Am. Assoc. Petrol. Geol. Bull., 64:1179-1209.

LePichon, X., Melguen, M., and Sibuet, J.-C., 1978. A schematic model of the evolution of the South Atlantic. In Charnock, H., and Deacon G. (Eds.), Advances in Oceanography: New York (Plenum), pp. 1-48.

Ludwig, W. J., and Krasheninnikov, V., 1980. Tertiary and Cretaceous paleoenvironments in the southwest Atlantic Ocean: Preliminary results of DSDP Leg 71. Geol. Soc. Am. Bull., 91(1):655-664.

Schlanger, S. O., and Jenkyns, H. C., 1976. Cretaceous oceanic anoxic events: Causes and consequences. Geol. Mijnbouw, 55:179-184.

Supko, P. R., Perch-Nielsen, K., et al., 1977. Init. Repts. DSDP, 39: Washington (U.S. Govt. Printing Office).
Tissot, B., Demaison, G. J., and Masson, P. 1980. Paleoenvironment and petroleum potential of the mid-Cretaceous black shales in the Atlantic basins. Am. Assoc. Petrol. Geol. Bull., 64:2051-2063.

van Andel, Tj. H., Thiede, J., Slater, J. G., and Hay, W. W., 1977. Depositional history of the South Atlantic Ocean during the last 125 million years. J. Geol., 85:651-697.

Weissert, H., 1981. The environment of deposition of black shales in the Early Cretaceous: An ongoing controversy. Soc. Econ. Paleontol. Mineral., Spec. Publ., 32:547-560.

Welte, D. H., Cornford, C., and Rullkötter, J., 1979. Hydrocarbon source rocks in deep-sea sediments. Proc. 11th Ann. Offshore Tech. Conf. (Houston), 1:457-464.

Date of Initial Receipt: October 12, 1982
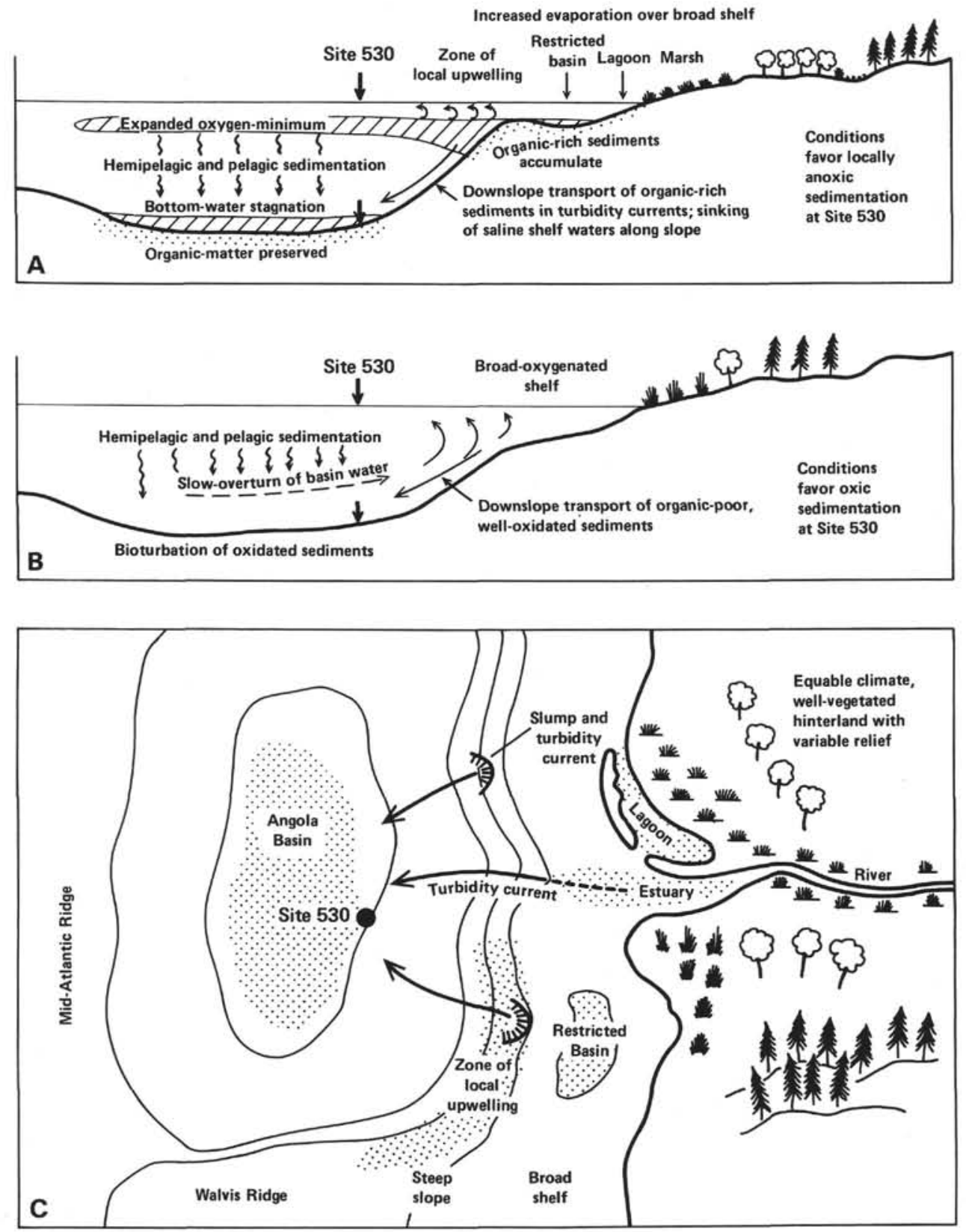

Figure 5. Schematic cross-sections and map through part of middle Cretaceous Angola Basin showing: A. Range of conditions favoring locally anoxic sedimentation. B. Range of conditions favoring oxic sedimentation. C. Regional variability within basin. Stippled areas indicate areas where organic matter is preserved in the sediment. 

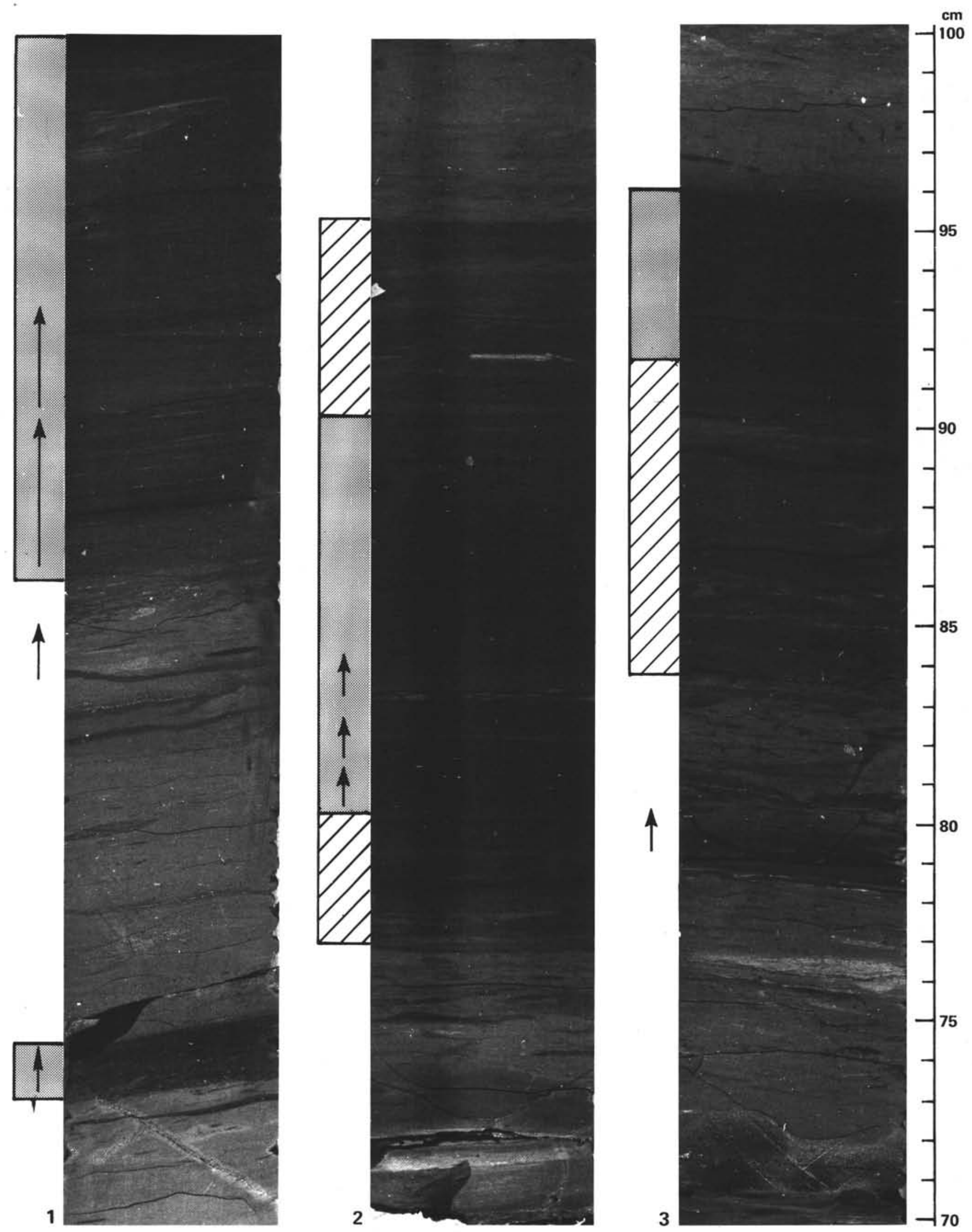

Plate 1. Details of black shale layers from Site 530. 1. Section 105-4. 2. Section 96-4. 3. Section 96-5. Shaded box at side indicates black shale, oblique hachure is gray shale, and the unshaded parts are greenish mudstones-marlstones. Arrows show locations of thin turbidites. 

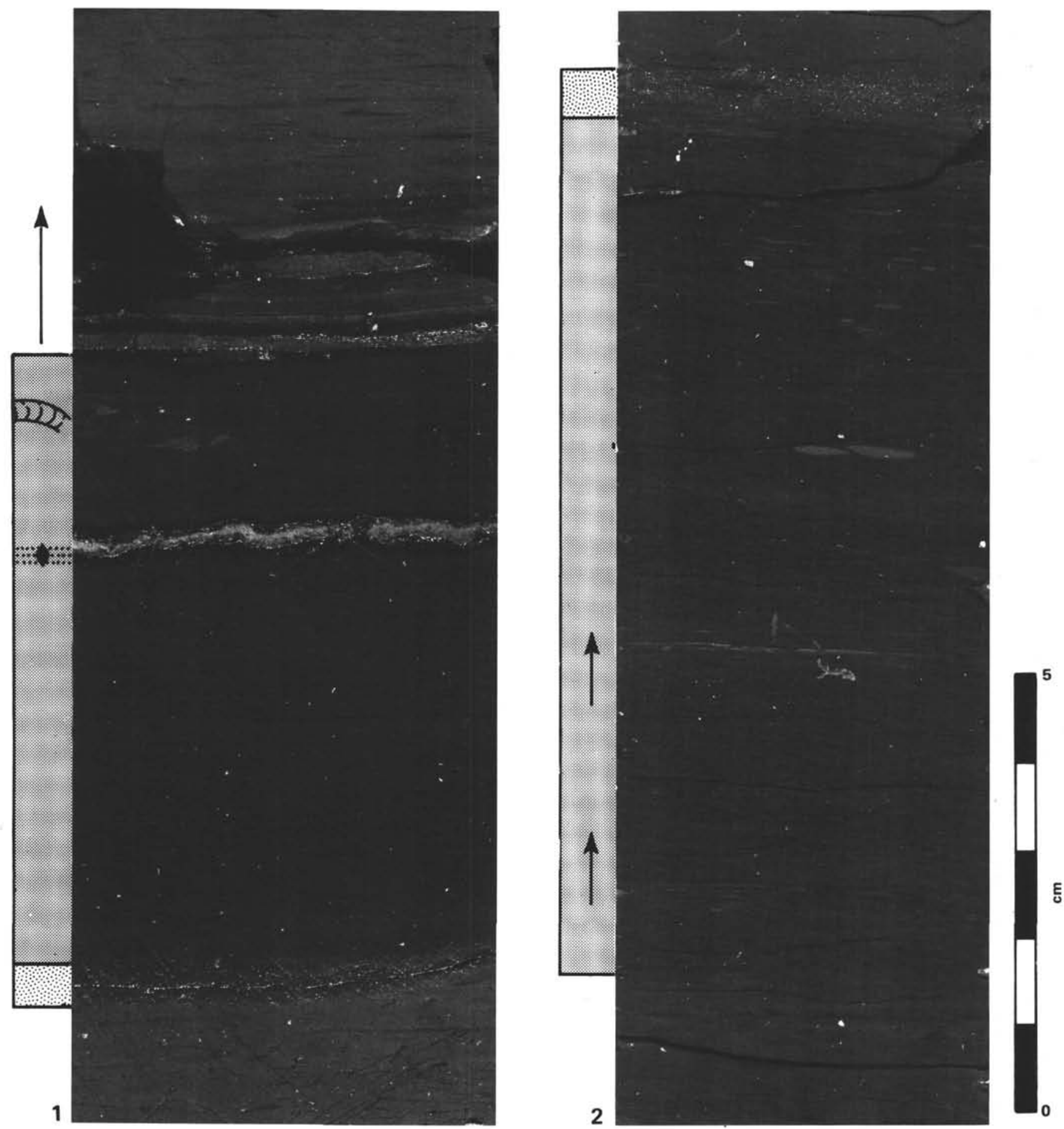

Plate 2. Details of black shale layers from Site 530. 1. Section 98-3 and 2. Section 100-1. Shaded box represents black shale, stipple represents gray muddy sandstone. Zoophycos burrow and pyritic siltstone shown in 1; locations of two thin turbidite layers are shown by arrows in 2. 